Copying. This journal is registered with the Copyright Clearance Center, 27 Congress Street, Salem, Mass. 01970. Organizations in the USA who are also registered with C.C.C. may therefore copy material (beyond the limits permitted by sections 107 and 108 of the US copyright law) subject to payment to C.C.C. of the per-copy fee of $\$ 5.00$. This consent does not extend to multiple copying for promotional or commercial purposes. Code $0007-1145 / 88 \$ 5.00+.00$.

ISI Tear Sheet Service, 3501 Market Street, Philadelphia, Pennsylvania 19104, USA, is authorized to supply single copies of separate articles for private use only.

For all other use, permission should be sought from Cambridge or the American Branch of Cambridge University Press.

The Proceedings of the Nutrition Society, published by the Cambridge University Press, in part record meetings of the Symposium type, at which experts in a particular field are invited by Council to make contributions on specific parts of it and at which general discussion follows these invited contributions. The contributions will be published in extenso; such summaries of the ensuing discussions as circumstances warrant may also be published. The Society also holds scientific meetings at which papers are communicated by members and others on original work carried out by them. It is proposed at present to publish summaries of the papers read at each meeting, each communication being recorded in the Society's Proceedings by means of an abstract not exceeding in length 400 words or the equivalent space in print. The Proceedings are published three times a year.

The subscription to the Proceedings is $£ 69.00$ net (US $\$ 160.00$ in USA and Canada). Single issues are $£ 25.00$ (US $\$ 61.00$ in the USA and Canada) each; postage extra.

\title{
SUBMITTING PAPERS
}

Papers should be sent to Professor M. I. Gurr, British Journal of Nutrition, c/o AFRC Institute of Food Research, Reading Laboratory, Shinfield, Reading, Berkshire RG2 9AT. They should be written concisely and must represent the results of original nutritional research (or exceptionally a new interpretation of existing knowledge) not previously published. Full requirements and details of how papers should be prepared are given in Directions to Contributors printed in Part 1 of each volume but authors should also consult a recent issue to acquaint themselves with the style and conventions of the Journal. Submitted papers (preferably three copies) should be accompanied by a signed statement to the effect that the author accepts the conditions laid down in Directions to Contributors.

\section{DIRECTIONS TO CONTRIBUTORS-CHANGE IN REFERENCE STYLE}

In 1989 references will appear with full paper titles. When submitting papers please ensure that the reference list conforms to the new style (for example, see Directions to Contributors). 


\title{
The British Journal of Nutrition
}

\author{
Volume 60 No. 2 September 1988
}

\author{
CONTENTS
}

SUBJECT MATTER IN BRIEF

$193-195$

\section{CLINICAL AND HUMAN NUTRITION PAPERS}

\section{Studies Relevant to Human Nutrition}

WyatT G. M., HoRN N., GeE J. M. \& JohnSON I. T. Intestinal microflora and gastrointestinal adaptation in the rat in response to non-digestible dietary polysaccharides

Fairweather-Tait Susan J., Southon Susan \& Piper Zoe. The effect of alcoholic beverages on iron and zinc metabolism in the rat

JACKSON M. J., Roberts J. \& EDWARDS R. H. T. Effects of dietary-fish-oil feeding on muscle growth and damage in the rat

Walter D. J., Eastwood M. A., Brydon W. G. \& Elton R. A. Fermentation of wheat bran and gum arabic in rats fed on an elemental diet

\section{GENERAL NUTRITION PAPERS}

Blomhoff Rune, Berg Trond \& Norum KaARE R. Distribution of retinol in rat liver cells: effect of age, sex and nutritional status

Spencer D., Higgins T. J. V., Freer M., Dove H. \& CoOmbe J. B. Monitoring the fate of dietary proteins in rumen fluid using gel electrophoresis

Symonds M. E., Bryant M. J., Shepherd D. A. L. \& Lomax M. A. Glucose metabolism in shorn and unshorn pregnant sheep

Sutton J. D., Hart I. C., Morant S. V., Schuller E. \& Simmonds A. D. Feeding frequency for lactating cows: diurnal patterns of hormones and metabolites in peripheral blood in relation to milk-fat concentration

Horigome T., Kumar R. \& OKamoto K. Effects of condensed tannins prepared from leaves of fodder plants on digestive enzymes in vitro and in the intestine of rats

MAKKAR H. P. S., Singh B. \& DAWRA R. K. Effect of tannin-rich leaves of oak (Quercus incana) on various microbial enzyme activities of the bovine rumen

Thomas C., GibBs B. G., Beever D. E. \& Thurnham B. R. The effect of date of cut and barley substitution on gain and on the efficiency of utilization of grass silage by growing cattle. 1. Gains in live weight and its components

Beever D. E., Cammell S. B., Thomas C., Spooner M. C., Haines M. J. \& Gale D. L. The effect of date of cut and barley substitution on gain and on the efficiency of utilization of grass silage by growing cattle. 2.v Nutrient supply and energy partition

Noguchi Tadashi, Nam Taek Jeong, Kato Hisanori \& Naito Hiroshi. Further studies on the nutritional factors affecting the urinary excretion of acid-soluble peptides in rats

BeEver D. E. Protein metabolism

Dawson J. M., Bruce C. I., Buttery P. J., Gill M. \& Beever D. E. Protein
in the rumen of silage-fed steers: effect of fishmeal supplementation

RothWell NANCY J. \& STOCK MiChaEl.J. Increased body-weight gain and body protein in castrated and adrenalectomized rats treated with clenbuterol

COPPEN D. E. \& DAVIES N. T. Studies on the roles of apotransferrin and caeruloplasmin ( $E C$ 1.16.3.1) on iron absorption in copper-deficient rats using an isolated vascularlyand luminally-perfused intestinal preparation

Dove $\mathrm{H}$. Estimation of the intake of milk by lambs, from the turnover of deuterium- or tritium-labelled water

Narce Michel, Poisson Jean-Pierre, Belleville Jacques \& Chanussot Bernard. Time-course effects of protein malnutrition on hepatic fatty acids $\Delta 6$ and $\Delta 5$ desaturation in the growing rat 